\title{
Commonwealth Navies as Seen by the United States Navy, 1910-2010
}

\section{John B. Hattendorf ${ }^{1}$}

Aux États-Unis, les perspectives sur les marines du Commonwealth au cours du siècle passé ont varié, car les Américains ont considéré la question en termes de contextes différents. Au départ, certains officiers clairvoyants de la Marine américaine, tels A.T. Mahan et W.S. Sims, ont $v u$ le potentiel de d'entente et de coopération entre les marines " anglosaxonnes ». Pendant la même période, les forces navales du Commonwealth ont joué un rôle dans la planification de guerre navale américaine. Avant les années 1930, beaucoup de ces plans ont été vus comme des tests de capacité de la Marine américaine contre une puissance à peu près égale et, donc, sur le plan académique ont illustré le rôle de la puissance navale, mais néanmoins ont révélé des vues intéressantes sur les marines du Commonwealth. Avec l'avènement de la seconde guerre mondiale, les relations navales ont changé de façon spectaculaire, en tant que la Marine américaine a travaillé en étroite collaboration avec les forces britanniques et du Commonwealth pour combattre l'ennemi commun. Cela a continué jusqu'à la période de la guerre froide avec des alliances de défense avec l'OTAN et autres. Cette entente persiste avec l'actuelle "stratégie maritime coopérative pour le 2le siècle 》 des États-Unis.

In 1977, Professor Robin Winks of Yale University famously observed that, "Americans cannot understand their own history without understanding Canadian history. Conversely, Canadians cannot understand their history without understanding American history." 2 At the same time, Winks went on to point out the additional value to be found in comparing and contrasting the histories of Australia, Canada, New Zealand, and the United States as they separately grew within the shared heritage of the English-speaking peoples, developing their own particular national identities as they merged with other

1 The opinions and judgments in this paper are the personal academic views of the author on historical issues and do not reflect any current policy or official view of the United States of America, the United States Navy, the Naval War College, or any other agency.

2 Robin W. Winks, The Relevance of Canadian History: The 1977 Joanne Goodman Lectures (Toronto: Macmillan of Canada, 1979), p. 60.

The Northern Mariner/Le marin du nord XXIV, Nos. 3 \& 4 (Jul. \& Oct. 2014), 157-175 Canadian Military History 23, Nos. 3 \& 4 (Summer \& Autumn 2014), 157-175 
cultural influences under differing geographical and historical circumstances. ${ }^{3}$

The comparative development of navies and the roles they each undertook within those differing national trajectories is a broad subject that is easier to comprehend when limited to the twentieth century development of the Australian, Canadian, and New Zealand navies, and much more problematic to try to link to the experience of the United States at comparative stages of its naval development one hundred years earlier in the different technological context of the nineteenth century.

A related, but more modest alternative, approach is to look for samples of the range of contemporary American perceptions of Commonwealth naval development in the twentieth century. Over the span of the century between 1910 and 2010, the United States Navy has viewed Commonwealth navies in a variety of ways and from several different perspectives. Coming from different quarters of the navy and from different levels, these views were sometimes contradictory, but nevertheless show a maturing appreciation as these naval forces grew from very small nascent forces into full-fledged navies. Among them, the naval forces of Canada had a special significance by virtue of their geographical proximity to the Unites States and their natural home in sharing North American waters. Nevertheless, the naval forces in India, Australia, and New Zealand were not overlooked as American naval officers assessed the world naval situation

At the outset, in the early twentieth century, American naval officers clearly understood that the dominion naval forces were part of the larger capabilities of the Royal Navy, although they seemed not entirely unaware of the debates and issues arising between the Cabinet in London, the Admiralty, the Colonial Office, and the various dominion governments about these forces.

One of the earliest American comments about dominion naval forces came even at the very opening years of the twentieth century, just after the establishment of the Australian navy, in the context of discussion about what was then turned imperial federation'. As early as 1902, Captain Alfred Thayer Mahan published an article on this subject. $^{4}$ In this, Mahan commented on the successful experience of the United States in developing its thirteen previously separate English colonies into an effective federation. Going further, Mahan commented,

The American Commonwealth and the British Empire have had many jars in the past, the memory of which has not wholly; but more and more clearly are coming into view the permanent conditions that from the first have existed.... In language, law, and political traditions there is fundamental identity; and in blood also....

Two years later, in July 1904, Mahan was the guest of honor at a luncheon in London hosted by the Imperial Federation (Defence) Committee. The well-known writer

$3 \quad$ Ibid., 22-37.

4 A.T. Mahan "Motives to Imperial Federation," National Review; International Monthly (May 1902), reprinted in Retrospect and Prospect: Studies in International Relations Naval and Political. (Boston: Little, Brown, and Company, 1902), 89-135.

5 Mahan, Retrospect and Prospect, 134. 
on imperial defense issues, Sir John Colomb, was in the chair. In introducing Mahan to the distinguished group that had gathered for the occasion, Colomb declared:

The object of the Royal Navy of the United Kingdom, in its truest aspect, is not to make wars, but to prevent them. And I take it that the Navy of which Captain Mahan has been a distinguished ornament, has, with ours, that common mission in the future. The great American Commonwealth of which Captain Mahan is a distinguished citizen, and the British Empire, of which we are all ourselves citizens, have a great common interest in the peace of the sea. ${ }^{6}$

Colomb went on to draw Mahan's attention to the words of W.B. Dally, who as chief minister of New South Wales twenty or thirty years previously had suggested "Let there be one Navy, under the rule of a single Admiralty - a Navy in which the colonies shall be as much integrated as the Mother country, which shall be theirs as well as hers, and on which they may all rely in time of danger." 7

Mahan's response to all this was revealing. Linking the United States to this issue, Mahan commented, "...as the sympathies of the people who speak the same tongues widen, like those of the various communities under the British flag and our own are doing, that as they grow together there will be an approximation of the period which we have heard much - the federation of the world." ${ }^{8}$

In 1910, Commander William S. Sims visited London in command of the battleship USS Minnesota and expressed similar sentiments. Sims, who would later become the U.S. Navy's most famous and successful commander in World War I, had been born in Port Hope, Ontario, in 1858 and was raised there until the age of ten, when his American-born father and Canadian mother moved their family to the United States. During his port visit, the Lord Mayor of London ended a week of courtesy calls, parties, and festivities by hosting Sims with the officers and men of Minnesota to a luncheon at Guildhall on 3 December 1910. In a closing speech of thanks, Sims declared, "If the time ever comes when the British Empire is seriously menaced by an external enemy, it is my opinion that you may count upon every man, every dollar, every drop of blood, of your kindred across the sea." 9 His remarks were enthusiastically applauded by those present, but earned Sims a public reprimand from President William Howard Taft. Half a dozen years later in 1917 in the midst of the war with Germany, Taft noted "The ways of history are strange. When I was President I reprimanded an officer for saying exactly what he is doing now. That officer was Commander, now Vice Admiral, Sims in command of the American Navy in Europe." 10

6 Captain A.T. Mahan on Imperial Federation. Speech delivered at a Dinner of the Imperial Federation (Defence) Committee on July 6 ${ }^{\text {th }}$ 1904. The Right Hon. Sir John Colomb, K.C.M.G., M.P., in the chair (London: Imperial Federation (Defence) Committee, 1904), 1-2. Ibid.

$8 \quad$ Ibid.

9 Quoted in Elting E. Morison, Admiral Sims and the Modern American Navy (Boston: Houghton Mifflin, 1942), 281.

Ibid., 284. 
At the same time, there was a separate current of American naval thinking. In the late nineteenth century, officers in both the U.S. Army and the U.S Navy were influenced by the successes of the German General Staff in Prussia's wars and began to think about various contingencies and to write war plans for them, a process that was entirely new in American thinking. In 1887, Lieutenant Charles C. Rogers completed a large 375-page study on Canada for the recently established Office of Naval Intelligence that included descriptions of major ports and an early plan of naval operations in the event of a war with Britain. ${ }^{11}$

About this time, American officers in both services had begun to think about the possibility of a war against Britain and to write plans for such a contingency based on the thought that Britain was the most dangerous possible enemy, even if not the most likely. ${ }^{12}$ While the army thought about an invasion of Canada, concentrating on the eastern part of the country with the capture of Quebec and Montreal and a strike at Vancouver with a foray to cut the Canadian Pacific rail line at Coteau Junction, ${ }^{13}$ the U.S. Navy saw itself vastly outnumbered by the Royal Navy. Mahan himself drafted a naval war plan in 1890 with a concept for the weak U.S. Navy to operate with a defensive-offensive strategy appropriate to a small power that kept the American main battle fleet in port, waiting for an opportune moment to attack its larger adversary, while minor American squadrons were stationed in Puget Sound and on Lake Ontario. To this, Mahan added a plan for a 15,000 man expeditionary force to land at St Margret's Bay, Nova Scotia, to attack Halifax and destroy the naval dockyard there. ${ }^{14}$

At a quite different level of perception, war college students in the United States were also aware of the existence of dominion naval forces as they worked on their academic exercises and war games. The Naval War College, founded in 1884, was the oldest of these institutions in the United States. Its sister institution, the U.S. Army War College opened nearly twenty years later in 1903. The U.S. Army War College's first president, Brigadier General Tasker Bliss, was keenly interested in joint service thinking and cooperation between the army and navy, having served as a young lieutenant in 1886-87 as the Naval War College's first military faculty member. From the outset, Bliss's interest led to the development of close connections between the two service colleges that represented the highest level of professional military education in the United States, and officers were soon exchanged as students and staff members at the two

11 Naval War College Archives, Record Group 8, Box 5 folder 1: "Canada" by Lieutenant Charles C. Rogers, Intelligence Officer, USS Galena, August 1887, corrected to May 1891.

12 Steven T. Ross, American War Plans, 1890-1939 (London and Portland, OR: Frank Cass, 2002), 7.

13 Ibid., 8. For the Canadian perspective, see also Richard Preston, The Defense of the Undefended Border: Planning for War in North America, 1867-1939 (Montreal: McGillQueens University Press, 1977).

14 Robert Seager II and Doris Maguire (eds.), Letters and Papers of Alfred Thayer Mahan (Annapolis: Naval Institute Press, 1977), vol. III, 559-578: "Contingency Plan in the Case of War with Great Britain, December 1890." 
colleges to promote inter-service cooperation. ${ }^{15}$ Along with this came some student exercises and war games that allowed the officer-students to work together.

A war game concerning the American contingency plan for war between the United States and the United Kingdom, by now named War Plan RED, was the subject that students at the Army War College examined during the academic year 1911-12. In contrast to earlier plans, it suggested a reason why war might occur between the two countries and looked at the situation with a global perspective. The war game scenario

\begin{tabular}{|c|c|c|}
\hline & Officers & Men \\
\hline Fleet in commission & 7,414 & 98,381 \\
\hline Coast Guard & 310 & 2,790 \\
\hline Royal Marines & 483 & 16,477 \\
\hline Training & 805 & 5,199 \\
\hline Special Services & 300 & 1,391 \\
\hline $\begin{array}{l}\text { Royal Fleet Reserve, } \\
90 \% \text { of } 21,943\end{array}$ & 0 & $\begin{array}{r}19,7491 \\
9,749 \\
\end{array}$ \\
\hline $\begin{array}{l}\text { Royal Naval Reserve, } \\
25 \% \text { of } 18,560\end{array}$ & 415 & 4,225 \\
\hline $\begin{array}{l}\text { Royal Naval Volunteer } \\
\text { Reserve }\end{array}$ & 168 & 3,057 \\
\hline $\begin{array}{l}\text { Officers retired List } \\
\text { (shore duty only) }\end{array}$ & 1,008 & - \\
\hline Australian Naval Forces & 180 & 1,127 \\
\hline Canadian Naval Forces & 60 & 810 \\
\hline Royal Indian Marine & 215 & - \\
\hline Total & 11,358 & 158,081 \\
\hline Available after 30 days & 830 & 26,150 \\
\hline Available after 3 months & 5,250 & \\
\hline Grand Total & 12,188 & 189,481 \\
\hline
\end{tabular}

Table 1: [RED Naval] Personnel Available Immediately on Declaration of War. $^{16}$ was based on a situation in which RED had caused BLUE (i.e., the United States) to declare war, when RED dispatched an army division and a mounted brigade, totaling 22,000 men in fast transports, escorted by the first cruiser squadron sailing from Southampton to reinforce the army in Canada, and landed at Quebec.

As this was occurring a RED flying squadron based on Bermuda attacked BLUE commerce and acquired information on the BLUE naval dispositions. The main RED fleet mobilized and sailed from Bantry Bay in Ireland for Halifax, where it arrived on the ninth day to join the flying squadron. The main fleet began operations against the BLUE fleet on the fourteenth day looking for a decisive action or to block it up in port. Meanwhile RED reinforced its China squadron at Singapore and proceeded to attack the outlying BLUE possession of Guam. An additional reinforcement of RED's China squadron arrived on the $31^{\text {st }}$ day and created a balance of naval power in the Pacific. At this point, a second expedition of 80,638 men begins to land on BLUE's Atlantic coast in the vicinity of New York, followed by another 79,927 men on day 56 . In the Pacific, an expedition of 37,782 men from Australian and New Zealand forces reached

15 John B. Hattendorf, B. Mitchell Simpson III, and John R. Wadleigh, Sailors and Scholars: The Centennial History of the Naval War College (Newport, RI: U.S. Naval War College Press, 1984), 70-71.

16 Naval War College Archives, RG 8, Box 49, file 1, "Organization and Distribution of RED Naval Forces in Case of War with BLUE" by Commander McCully, 7-8. Also in RG 8, Box 4 , file 3. 
Suva, Fiji Islands, on day 30, from whence it would sail via Fanning Island to attack the Panama Canal as soon as RED had secured control of the Pacific. ${ }^{17}$

In this war game, RED completely overcame any resistance that BLUE could offer, although it was apparent that BLUE's best chance for defense lay in a quick offensive against Cornwall and Ottawa in the east and Winnipeg and Mission Junction in the west, with the object of breaking up Canadian militia concentrations, destroying canals and railroads and dividing RED's main expeditionary force. At the same time, BLUE's ability to exert naval control of the Great Lakes would be important. That appeared to be possible in Lakes Superior, Michigan, Huron, and Lake St. Clair, but "difficult in Lake Erie and probably impossible at first in Lake Ontario." 18

The calculations for all this involved a consideration of dominion navies as part of the RED's forces. A detailed chart provided the statistical information (see Table 1.)

In considering the roles of Australian, Canadian, and Indian naval forces in this scenario, the American naval officers saw the greatest use of these forces in partially manning the Royal Navy's local squadrons on the Australian station, East Indian Squadron, and in reserve positions in Canada, thereby allowing the equivalent number of regularly trained officers and men for active service in the war against the United States. ${ }^{19}$

Between 1917 and 1918, the United States Navy operated successfully with the Royal Navy in European waters under Admiral Sims's command. An American squadron of battleships joined the Grand Fleet, while destroyers, naval aircraft, and transports carried out a wide range of cooperative operations. ${ }^{20}$ However in 1919, the peace negotiations at Paris raised great tension between the United States and Britain. While both agreed on the basic questions in dealing with the defeat of the Central Powers, major disagreement took place when the United States demanded naval parity with Great Britain with a United States Navy that was 'second to none'. The so-called 'Naval Battle of Paris' took place in March 1919, in which Americans showed their suspicions about British claims for continued naval supremacy and feared that Britain's supremacy and use of naval blockade against Germany might lead to a blockade against American ports in a future conflict. For this reason, American naval officers proposed that Germany retain a small naval fleet as a counterweight to the Royal Navy. For the same reason, they considered, too, the idea of a League of Nations naval force. In a wide range of other considerations in these negotiations, the subject of Canada arose.

17 Naval War College Archives, RG 8, Box 49, file 1, UNOpP. Army War College Work - 19111912 - "War Plan, BLUE versus RED." The U.S. naval officers who participated in this at the Army War College were Captain McLean and Commander N.A. McCully. Ibid., Summary, 3.

19 Ibid., 7.

20 See E.E. Morison, Sims; Williams S. Sims, The Victory at Sea (Garden City, NJ: Doubleday, 1920, reprinted Annapolis: Naval Institute Press, 1984, with an introduction by David F. Trask); William N. Still, Jr., Crisis at Sea: The United States Navy in European Waters in World War I (Gainesville FL: University Press of Florida, 2006). 
In analyzing the post-war situation, American naval planners first saw a number of reasons why a future war between the United States and Great Britain would be unlikely. Among these factors were the economic dependence of Great Britain on the United States, the proximity of Canada to the United States, and the possible lack of colonial support for a war against the United States unless British dominions saw it as a just war. ${ }^{21}$ On the other hand, there were a number of reasons why a future war might break out. The main issues here were the disparity between British and American views of freedom of the seas, particularly in regard to belligerent rights. American naval officers were particularly sensitive to Britain's reluctance to codify maritime international law and to apply the most liberal interpretation of belligerent rights on the High Seas and saw this as one of several reasons for maintaining a navy equal to Britain's. As an example of the type of crisis that could arise, the U.S. Naval Advisory Staff in Paris used a Canadian contingency as an example:

...if Canada should attempt to gain her independence from Great Britain by force, and if the United States remained neutral, it is the British contention that Great Britain could blockade every port of the United States and could so regulate our imports that we could spare none for exportation to Canada. This is not International law, but an application of the law of force to neutrals. The only reply is the presence of a potential [U.S. naval] force that will secure the abandonment of the contention. ${ }^{22}$

The Washington Naval Disarmament Treaty of 1921-22 formally established the principles of nominal naval parity with Britain that the United States had been seeking during and immediately after the First World War, ${ }^{23}$ although the Unites States did not immediately build up to treaty strength, allowing the Royal Navy to remain numerically and qualitatively superior through the 1920s. Nevertheless, American naval officers remained distrustful of Britain. While they acknowledged war was unlikely, they still believed the Royal Navy might be used in its traditional role to protect and to further British trade at the expense of American interests. The underlying cause for such a war would most likely be a British attempt to promote its weakening trade situation by attacking the United States, its principal economic competitor. ${ }^{24}$

In 1923, the U.S. Office of Naval Intelligence Monthly Information Bulletin reported that former British Prime Minister David Lloyd George had said that the only country that gave any concern for a future war in the near future was the United States

21 Michael Simpson, ed. Anglo-American Naval Relations, 1917-1919, Publications of the Navy Records Society, vol. 130. (Aldershot: Scolar Press for the Navy Records Society, 1991), 579: Document 435: U.S. Planning Section, early 1919.

22 Ibid., 603: Document 448: Memorandum of the U.S. Naval Advisory Staff, Paris, 7 April 1919.

23 J. Kenneth McDonald, "The Washington Conference and the Balance of Power, 1921-22," in John B. Hattendorf and Robert S. Jordan (eds.), Maritime Strategy and the Balance of Power: Britain and America in the Twentieth Century (London: Macmillan, 1989), 189-210.

24 Christopher M. Bell, "Thinking the Unthinkable: British and American Naval Strategies for an Anglo-American War, 1918-1931," The International History Review XIX:4 (November 1997), 757-1,008. 
and that the points of friction between them were (1) the Irish question, (2) naval rivalry, and (3) the debt. ${ }^{25}$

If such a war took place, British planners saw the eastern Atlantic, Canada, and the Far East as the most likely theatres for it to play out. ${ }^{26}$ Yet, American naval planners looked at the contingency more narrowly in terms of the defense of the western hemisphere. By 1930, the American War Plan RED was still basically a defensive plan in which CRIMSON (Canada) played a central role with the worst-case scenario of British forces invading the United States from Canada. At this point, American war planners saw Canada as the most sensitive and productive target that they could attack in a war with Britain. Even as late as 1930, American officers could not easily imagine Canada remaining neutral. Backed up by extensive analysis through war games at the Naval War College, American naval plans called for an attack on Halifax and other ports to prevent British forces from reaching Canada with the U.S. remaining in a defensive position waiting for an opportunity to engage. ${ }^{27}$

Through the 1930s, a gradual shift in American naval attitudes toward Canada took place. Beginning in 1933, the Naval War College's Intelligence Department began to undertake a series of detailed studies on areas of strategic interest which were paralleled by war games. The volumes on Canada were revised in 1935-36 and again in 1940, allowing some basis to record some changing American naval perceptions. In the later versions the above assessment was not repeated. In 1935-36, the overall assessment of the contingencies had drifted further away from the probability of an actual war and moved to more of an academic exercise. In regard to War Plan RED, the study concluded, "We have, theoretically, a close approximation in parity, in the two navies, which are most interesting and convenient for use in demonstrating the principles of naval warfare." 28 At the same time, the war scenarios had changed from purely RED versus BLUE to a range of other situations, including:

CRIMSON versus BLUE

CRIMSON and RED versus BLUE

RED versus BLUE, with CRIMSON neutral

CRIMSON and RED plus others versus BLUE. ${ }^{29}$

At the same time, the study explicitly described the Royal Canadian Navy for the first time, but noting only briefly that it "consists of 550 of all ranks, 500 reserves, and 1,000 Naval Volunteer Reservists. It comprises one destroyer and two minesweepers based at Halifax: and a similar group based at Vancouver." 30

25 "British Dominions," Office of Naval Intelligence. Monthly Information Bulletin. No 7 (1923), 2-23. Lloyd George quoted at p. 22.

26 Bell, “Thinking," 799-800.

27 Bell, "Thinking," 802; Michael Vlahos, The Blue Sword: The Naval War College and the American Mission, 1919-1941 (Newport, RI: Naval War College Press, 1980), 99-112.

28 Vlahos, The Blue Sword (1935-36), Part II, 1.

29 Ibid, Part 1, 28

30 Ibid. 
By 1937, the Naval War College had extended its research on this subject of Canada, and invited the U.S. Minister to Canada, Norman Armour, to give a detailed lecture on Canada as well as giving him a series of six in-depth questions to answer in writing after he had returned to Ottawa. In making this presentation, Armour explained fully for Naval War College students the history of the development of Canada and the other dominions to an independent status, which he dated from the 1917 Imperial War Council resolution recording its recommendation that full recognition of the dominions should be given to their being autonomous nations of the imperial commonwealth. $\mathrm{He}$ told his American audience that in Canada there were three large opinion groups on the matter of defense issues. First, there were the isolationists, who preferred to rely on Canada's geographic remoteness, the Royal Navy, and the Monroe Doctrine for protection. A second group was the collectivists, who pinned their hopes on collective security and the League of Nations. Then there was a large group of middle-of-the road people who would cooperate with the Empire and the League in so far as this can be done without involving Canada in any conflict not directly involving her national interests. "They contend," he said, "that having reached the status of a sovereign nation, Canada should have a defense force sufficient to maintain the dignity of her position." 31

Armour then went on to explain the current political debates in Parliament on the 1937 Canadian defense estimate amounting to $\$ 34$ million. As part of this he outlined the parliamentary history behind the creation of the Canadian navy going back to the 1909 debate as to whether to give dreadnoughts to Britain or to create a Canadian navy and linked these discussions to the recent speech by the leader of the opposition, former Prime Minister R.B. Bennett, in which he paid tribute to Sir Wilfred Laurier's naval policy that resulted in the 1910 Naval Service Act, thus supporting the Mackenzie King government's plans for naval expansion. Armour underscored his point that "Canada had no intention of becoming involved in any conflict where her interests are not at stake, either in Europe or in the Pacific." 32 Going further, he said "whether she has at her command today a force adequate to maintain her neutrality or will have such a force in the near future, taking into account the heavily charged state of the British shipyards and the fact that Canadian shipyards and aviation factories are limited in size and output, is something that you can answer better than I." ${ }^{33}$

A revision to the Naval War College's study was apparently already in progress when the war with Germany broke out in September 1939 and was completed in midFebruary1940. Noting that the war "had already profoundly affected all phases of Canadian life, ${ }^{34}$ the report went on to note that:

The Canadian Navy is almost negligible, in spite of the addition of the

31 Naval War College Archives, RG 8, Box 6, file 2. Norman Armour, "Canada." Lecture delivered 26 April 1937, with written answers to six questions submitted later. Quotation from main text of the lecture, 10 .

34 Naval War College Archives, RG 8, box 6:Studies of Strategic Areas: Canada (1939-1940), 24. 
British flotilla leader Assiniboine and requisitioning of 40 commercial vessels for naval service. A fairly large number of small anti-submarine motor boats and aircraft salvage craft have also been added to the Navy. ${ }^{35}$

Concluding the study, the Naval War College authors reached a quite new and different assessment of Canada, recognizing for the first time in such American naval studies its independent position: "This extremely brief review of Canada at war indicates," they wrote, "that if the United States ever undertook her defense, the Canadians can be of major help. Conversely, a political upset would make her a rather dangerous enemy." 36

Within a week after Britain's declaration of war against Germany in 1939, the dominions of Australia, Canada, New Zealand, and South Africa had each announced their support for Britain. ${ }^{37}$ From the beginning of his administration in 1933, President Franklin D. Roosevelt was interested in closer U.S. Canadian relations. With the approaching expiration on 31 December 1936 of the London Naval Treaty of 1930, British and American officials engaged in long series of preliminary diplomatic negotiations prior to the Second London Naval Conference scheduled for 1935. Britain faced an uneasy situation in the light of America's neutral stance. Britain had few reliable allies in Europe and, in the light of the rise of Hitler and German rearmament, British leaders were seriously considering making an accommodation with Japan. In November 1934, President Roosevelt told his negotiator in London, Norman H. Davis:

I hope that you will keep two definite considerations always in mind. First that [Sir John] Simon [a National Liberal] and a few other Tories must be constantly impressed with the simple fact that if Great Britain is even suspected of preferring to play with Japan to playing with us, I shall be compelled, in the interests of American security to approach public sentiment in Canada, Australia, New Zealand, and South Africa in a definite effort to make these dominions understand clearly that their future security is linked with the US. ${ }^{38}$

The construction of an Alaskan military highway ${ }^{39}$ was another of the early direct issues to arise with Canada and the United States, followed in January 1938 with a brief trip to Washington by the Canadian Chief of Naval Staff Commodore Percy Nelles and Chief of the General Staff General E.C. Ashton for the initial very tentative exploration of possible Canadian-U.S. defense cooperation with Admiral Leahy and two American

35 Naval War College Archives, RG 8, box 6: D-Department of Intelligence, Naval War College, Studies of Strategic Areas: Canada. (1933), 27

36 Ibid.

37 R. Ovendale, 'Appeasement' and the English-speaking World: Britain, the United States, the Dominions, and the Policy of Appeasement, 1937-1939 (Cardiff, 1975), 300-314.

38 Michael Simpson, (ed.), Anglo-American Naval Relations, 1919-1939, Publications of the Navy Records Society, vol. 155 (London: Ashgate for the Navy Records Society, 2010), 203: Doc. 144, Roosevelt to Davis, 9 November 1934.

39 For the detailed history of this project, see Heath Twichell, Northwest Epic: Building the Alaska Highway (New York: St Martin's Press, 1992). 
generals. ${ }^{40}$ Over the following two years, political and practical pressure grew on both sides to develop some sort of formal security arrangement between the two countries, despite America's initial neutrality in the war against Germany. Separately, the United States had engaged in discussions in August 1940 with Britain to exchange fifty World War I destroyers for 99-year leases on six bases in the West Indies, Bermuda, and Newfoundland. While Canada was not a direct participant in these discussions, the issue had relevance. Even before all the details of this agreement had been reached, Prime Minister Mackenzie King and President Roosevelt met at Ogdensburg, New York, on 17 August 1940 and agreed to establish the Permanent Joint Board on Defense (PJBD) to study all aspects for the defense of the northern half of North America as a means to lead toward a defensive alliance. Each side had different expectations from the PJBD, but one of the first issues mentioned were ways that the Royal Canadian Navy might possibly be strengthened. ${ }^{41}$ With this beginning, the transition began from belligerent Canada and neutral America to an active alliance based on the practical basis of a shared understanding of the geopolitical situation and ideological objectives in the war. ${ }^{42}$

The basic plan of the cooperation was worked out in the American-British Conference (ABC-1) held between 29 January and 28 March 1941, and ABC-22, the plan for Canadian-American defense that assigned specific numbers of naval forces to work with each other. ${ }^{43}$ The experience of being an ally was entirely new to Americans in 1941. The United States had previously operated as an independent nation and had often taken a unilateral stance as a neutral power. Even in World War I, the United States had not been one of the allies, but rather an associated power. ${ }^{44}$

The fifty over-age American destroyers that the Royal Navy acquired were symbolically renamed in honor of towns that shared names in Britain, Canada, and the United States - names such as St. Mary's, Charleston, Chelsea, Georgetown, Broadway, Newark, and Newport; some of these went to the Royal Canadian Navy and named for rivers along the Canadian-U.S. border, such as Niagara and St. Clair. During the war years, American officers and men typically felt that they had good and friendly relations with both their British and Canadian counterparts. ${ }^{45}$ Americans thought that the rapid expansion of the Canadian navy from its small pre-war size of some 3,500 men and 13 ships to the fourth largest allied navy of 100,000 men and 400 ships also showed some lack of the professional influence that a larger corps of professionals with full training careers would have brought. Americans at the time believed that this showed as an

40 Galen Roger Perras, Franklin Roosevelt and the Origins of the Canadian-American Security Alliance, 1933-1945: Necessary, but Not Necessary Enough (Westport and London: Praeger, 1998), 39-40.

41 Perras, Franklin Roosevelt, 78-79.

42 John Herd Thompson and Stephen J. Randall, Canada and the United States: Ambivalent Allies $3^{\text {rd }}$ edition (Athens GA: University of Georgia Press, 2002), 154.

43 Steven T. Ross, U.S. War Plans, 1939-1945 (Malabar FL: Krieger Publishing, 2000), 18-22.

44 Ibid., 24.

45 Patrick Abbazia, Mr. Roosevelt's Navy: The Private War of the U.S. Atlantic Fleet, 19391942 (Annapolis: Naval Institute Press, 1975), 99. 
advantage in the Canadian navy's informality, its hard-fighting, and its aggressive individualism as well as a weakness in its lack of disciplined procedures and its lack of attention to routine maintenance and repair. ${ }^{46}$

In 1945, Admiral Sir James Somerville, RN, head of the British Admiralty Delegation in Washington, wrote to the British High Commissioner in Ottawa, Malcolm McDonald, that an influential American officer had related to him his own experience as a destroyer flotilla commander. He had been surprised in having to repeatedly reconcile differences between officers of the Royal Navy and Royal Canadian Navy, when he had in fact expected the Canadians to be the intermediary for the U.S. Navy.

$\mathrm{He}$ felt that in many cases friction which arose was due to hypersensitiveness on the part of Canadian Naval Officers, but at the same time he also felt that in certain circumstances British Naval Officers had failed to take due account of Canadians' sensitiveness or the fact that they were a young Navy lacking the experience of the British. ${ }^{47}$

Up to the time of the Japanese attack on Pearl Harbor, American naval officers had given relatively little attention to the other naval forces of the British Empire. Color plan code names did exist for SCARLET (Australia), GARNET (New Zealand), and RUBY (India). The Office of Naval Intelligence Monthly Bulletin did publish one or two short factual reports on the Australian, ${ }^{48}$ New Zealand, ${ }^{49}$ South African, ${ }^{50}$ and Indian ${ }^{51}$ navies, but there was little to be found on the Straits Settlements Volunteer Naval Reserve or on the Malay navy. In the 1930s, war planners did give thought to using Darwin in Australia as a refueling base. Nevertheless, on a higher strategic and diplomatic level, the Far East had been an important theme for discussion in Anglo-American discussions. During Neville Chamberlain's government, inconclusive Anglo-American naval staff conversations were held in 1937 and 1939 on this subject, as Malcolm Murfett has described in detail. ${ }^{52}$ Greg Kennedy has argued persuasively that the search for some

$46 \quad$ Ibid., 262-263, 318.

47 Michael Simpson (ed.), The Somerville Papers: Selections from the Private and Official Correspondence of Admiral of the Fleet Sir James Somerville, G.C.B., G.B.E., D.S.O, Publications of the Navy Records Society, vol. 134 (Aldershot: Scholar Press for the Navy Records Society, 1995), p. 655: Document 468, Somerville to Rt. Hon Malcolm MacDonald, 12 October [1945].

48 "Australia, destroyers of," Office of Naval Intelligence. Monthly Information Bulletin, No. 8 (1920), 41; "Naval Policies-Command on Australian Station," Office of Naval Intelligence, Monthly Information Bulletin, No. 7 (1923), 22.

49 "British Dominions and Naval Defense [New Zealand]," Office of Naval Intelligence. Monthly Information Bulletin, No. 10 (15 October 1922), 22-23; "New Zealand Naval Defense," Office of Naval Intelligence. Monthly Information Bulletin, No. 1 (January 1924), 48-50; No. 6 (June 1927), 55; No. 7 (July 1927), 58.

50 "South Africa," Office of Naval Intelligence. Monthly Information Bulletin, No 7 (July 1923), 14.

51 "Indian Navy," Office of Naval Intelligence. Monthly Information Bulletin, No. 7 (July 1928), 29.

52 Malcolm H. Murfett, Fool-Proof Relations: The Search for Anglo-American Naval Cooperation during the Chamberlain Years, $1937-1939$ (Singapore: National University of 
means of informal Anglo-American strategic cooperation in the Far East between 1933 and 1939 provided the key background for the eventual successful cooperation in the Atlantic and in the European theatre. ${ }^{53}$

In January 1938, the U.S. Navy had sent Captain Royall E. Ingersoll to London for conversations with the Admiralty. In his report to the American Chief of Naval Operations, Ingersoll summarized the British view that:

The UK cannot definitely commit the Dominions in any action in concert with the UK, as the Dominions like to maintain their independent dominion status. They feel sure that Canada, Australia and New Zealand will cooperate with them against Japan and that there would be no question that Australia and New Zealand ports could be used by the US, such as the Admiralty Islands (south of the Carolines), which are an Australian mandate. ${ }^{54}$

During that same series of meeting in January 1938, Ingersoll made a series of agreements with Captain T.S.V. Phillips, head of the Admiralty's War Plans Division. Among the many points that were established between them, it was agreed that the U.S. Navy would be responsible for operations against Japanese trade throughout the west coast of North and South America, including the Panama Canal and the passage around Cape Horn. In addition, the U.S. Navy also assumed responsibility for the general naval defense of the west coast of Canada. ${ }^{55}$

Immediately following the simultaneous coordinated Japanese attacks on Pearl Harbor, Manila, Singapore, and Hong Kong on 7/8 December 1941, Churchill and Roosevelt met in Washington for the Arcadia Conference that lasted from 24 December 1941 to 14 January 1942. British and American military and civilian leaders reformulated allied strategy in the light of the Japanese attack. The American Rainbow Five war plan had forbidden any major naval operations in the South Pacific west of $180^{\circ} \mathrm{W}$, thus eliminating Australia and New Zealand as operational areas, but the plan did allow minor BLUE naval forces carrying out escort duties and searching for enemy raiders to proceed to Australia and New Zealand in order to relieve Australian and New Zealand naval forces of these duties so as to free them to fight in Malayan waters. ${ }^{56}$

The decisions made at the Arcadia Conference changed the situation by creating a new strategic area for the Allies: ABDA Command, the multilateral command of American, British, Dutch, and Australian forces, whose mission was to hold Burma, the Malay Barrier, and Australia from the Japanese and to attack them, then driving

\section{Singapore Press, 1984).}

53 Greg Kennedy, Anglo-American Strategic Relations and the Far East, 1933-1939 (London: Frank Cass, 2002).

54 Simpson (ed.), Anglo-American Naval Relations, 1919-1939, p. 267: Document 200, Memorandum for the Chief of Naval Operations, January 1938.

55 Ibid., p. 278: Document 201, Record of Conservations: Agreed between Captain T.S.V. Phillips, RN, and Captain R.E. Ingersoll, USN. 11 January 1938.

56 Edward S. Miller, War Plan Orange: The U.S. Strategy to Defeat Japan, 1897-1945 (Annapolis: Naval Institute Press, 1991), 247. 
northward from the Dutch East Indies to recover the Philippines. While the Japanese quickly removed the brief-lived ABDA Command in the allied defeat at the battle of the Java Sea, the model for multinational naval cooperation that it represented became a major influence in some of the later initiatives that an American naval officer, who had served as a junior officer in ABDA Command, Richard G. Colbert, took in the late-1950s and 1960 s in the U.S. Navy and in NATO. ${ }^{57}$

With these beginnings in the Atlantic and the Pacific, the United States Navy began the close and successful naval cooperation that followed throughout the remainder of World War II. That huge topic with the details of change within it must be left aside in this overview. ${ }^{58}$ However, it useful to point out here that the Anglo-American Combined Chiefs of Staff (CCS), had essentially functioned as the command centre for AngloAmerican world-wide planning during the war, and through it American naval forces found the effective implementing basis for their wartime cooperation with Commonwealth navies. ${ }^{59}$ In the immediate post-war years from 1945 until the formation of NATO in 1949, there was no other organizational body that could assist in continuing the wartime cooperative measures into the post-war years. For that reason, there were repeated discussions about ways to continue and to adapt the functions of the Combined Chiefs of Staff to the post-war period.

By 1945, many American officials were beginning to come around to the views of British military and naval leaders that the Soviet Union was a matter for future concern and that the continuation of combined Anglo-American polices would be useful and important in the post-war situation. In June 1945, Admiral Somerville in Washington reported to London that his informal conversations with U.S. Secretary of the Navy James Forrestal and Chief of Naval Operations Fleet Admiral Ernest J. King indicated that they were both in favor of continuing the close U.S.-British relations in the post-war

57 See this author's "International Naval Co-operation and Admiral Richard G. Colbert: The Intertwining of a Career with an Idea," in W. A. B. Douglas (ed.), The RCN in Transition: Challenge and Response, 1910-1985 (Vancouver: University of British Columbia Press, 1988); revised and reprinted in Naval History and Maritime Strategy: Collected Essays (Newport, RI: Naval War College Press, 2000), 161-185; further revised and reprinted as "Admiral Richard G. Colbert: Pioneer in Building Global Maritime Partnerships," Naval War College Review 61:3 (Summer 2008), 109-130.

58 See instead, James Leutze, Bargaining for Supremacy: Anglo-American Naval Collaboration, 1937-1941 (Chapel Hill: University of North Carolina Press, 1977). W.A.B. Douglas, Roger Sarty, Michael Whitby, No Higher Purpose: the Official Operational History of the Royal Canadian Navy in the Second World War, Vol II Pt 1, 1939-1943 (St Catherines, ON: Vanwell, 2002), and Douglas, Sarty and Whitby, A Blue Water Navy: the Official Operational History of the Royal Canadian Navy in the Second World War, Vol II Pt 2, 1943-1945 (St Catherines, ON: Vanwell, 2007).

59 Richard A. Best, Jr., "Cooperation with Like-Minded Peoples:” British Influences on American Security Policy, 1945-1949 (Westport: Greenwood Press, 1986), 36. On this subject, see Sean M. Maloney, Securing Command of the Sea: NATO Naval Planning, 19481954 (Annapolis: Naval Institute Press, 1995), chapter 1: "Second World War Command Organization." 
period. King's successor as Chief of Naval Operations, Fleet Admiral Chester W. Nimitz, went further in June 1946 and advocated a "coordinated naval policy with appropriate members of the British Commonwealth of Nations" in dealing with the Soviet situation. ${ }^{60}$

While U.S.-British defense relations had became relatively informal in 1946-47, those between the U.S. and Canada remained formal and institutionalized through the Canada-U.S. Joint Defense Board that had been created in 1940. While Canada and the other Commonwealth countries had been represented through British military and naval leaders in the wartime Combined Chiefs of Staff, the United States now needed to develop a more direct way of cooperating with British Commonwealth countries. To deal with this issue, the Canada-U.S. Joint Defense Board recommended that combined Canadian-US Combined Chiefs of Staff be established on the lines of the wartime model with the British. While an attractive idea, the U.S. Joint Chiefs felt that it would create an awkward and unworkable precedent alongside similar arrangements that would eventually need to be made with a wide range of other allies. In its place, a Joint Canadian-U.S. Military Coordination Committee was established at the chiefs of staff level. This group proceeded immediately to develop a plan for the United States and Canada to jointly fight a war with a command structure that avoided the convoluted wartime system that had been based on Britain intermediation. At the same time, American naval commands were being reorganized on geographical terms to remedy some issues that the wartime experience had raised, but building upon it. This new system gave the U.S. Navy a world-wide system for its future naval operational command that was similar to Britain's pre-war system that largely continued after the war, but now needed to be adapted to relations with Commonwealth countries. ${ }^{61}$ Perceptions of the rising Soviet threat in 1946-47, led to a number of alternative plans and considerations for possible British-Canadian-U.S. defense relations. In 1948, the Brussels Treaty joined Britain, France, Belgium, Luxembourg and the Netherlands in the Western European Union with its Western European Defence Organization and Western European Chiefs of Staff Committee. With the creation of these organizations, both Canada and the United States needed to think in broader dimensions that included their mutual and cooperative defense. This took off in December 1948, when the United States joined the negotiating group to draft the North Atlantic Treaty signed in 1949. With the creation of NATO, It took more than two years to create an effective and fully accepted military and naval command structure. ${ }^{62}$ When completed, the naval dimension of national defense had been merged into a command structure in a coordinated manner that involved geographical, national, and functional assignments of forces. Through this arrangement, the U.S. Navy worked with the Canadian navy in its assigned roles, built on its proven capability in anti-submarine warfare and geographical maritime responsibilities in the north-western Atlantic (soon to be styled as 'CANLANT'). From

60 Quoted in Best, "Cooperation with Like-Minded Peoples," 32, from Harry S. Truman Library, Clark M. Clifford Papers: Nimitz to Forrestal, 23 July 1946, enclosed in Forrestal to Truman, 25 July 1946.

61 Maloney, Securing Command of the Sea, 51-54.

62 Ibid., 75ff; Robert S. Jordan, Alliance Strategy and Navies: The Evolution and Scope of NATO's Maritime Dimension (London: Pinter Publishers, 1990), 1-34. 
an American point of view, this relationship was a positive one, as a commander of the U.S. Navy's Atlantic Fleet anti-submarine forces and NATO Commander, Western Atlantic and Atlantic (COMWESTLANT and COMOCEANLANT), told U.S. Naval War College students:

Fortunately for us we have extremely close cooperation and liaison with CANCOMARLANT in Halifax. We have U.S. officers on his staff and I am fortunate to have some very fine Canadian Navy and Canadian Air Force officers on my staff and we do work extremely sympatical. ${ }^{63}$

Another important dimension of American perception of Commonwealth navies comes through officers on educational exchange to staff and war colleges. For example, in 1950, Captain John F. Davidson, USN, was assigned as an exchange student at the Canadian Defence College in Kingston. For him, it was an eye-opening experience and a highlight of his career that lead to a much deeper understanding and appreciation of Canada. When Davidson was in Canada, the United States (under the auspices of the United Nations) had just entered the Korean War. Canadian newspapers were full of criticism of the United States and its current foreign and military policy. In the midst of that criticism, Lester Pearson, then Canada's Secretary of State for Foreign Affairs, came to lecture at the Defence College. He had just returned to Canada after a trip to Washington, where he had conferred with President Truman and Secretary of State Dean Acheson. Davidson was impressed with the candor of Pearson's remarks, when Pearson told Davidson and his classmates in Kingston:

I want you to know, and I swear you to secrecy until hell freezes over. What you're reading in the paper is the result of my briefing with the press when I returned, but I want you to know what I really said to the President and to the Secretary of State. I said to them that the government of Canada was behind the United States 1,000\% about going into Korea with the United Nations and so on. But if that should be known in Canada, the government of Canada would fall the next day. We don't have the benefit of the U.S. system where you've got four years. We would fall the next day if the people of Canada thought that we approved of intervention in Korea. I want you to know. ${ }^{64}$

Such remarks were a revelation to Davidson. "That was the first time that I realized that what you read in the paper might not be representative: and that stood me in good stead when I was in political-military policy later...."65

Reflecting on his own educational experience in Canada and on the general approach to professional military education, Davidson said "I liked the systems I saw

63 Naval War College Archives, RG 15, Guest lectures: Vice Admiral Edmund B. Taylor, USN, "Deference of the Atlantic," 10 January 1963.

64 Naval War College, Naval Historical Collection, Oral History 101, Reminiscences of Rear Admiral John F. Davidson, U.S. Navy (Retired) (Annapolis: U.S. Naval Institute, 1986), 257.

Ibid., 258. 
going on up there, ${ }^{, 66}$ in which the Canadian Forces had all the prospective officers for all three different services in one entry level college and then sent them out to their respective services in the summer. "I don't think there was too much wrong with that system, because then I think they understood each other better than we do." ${ }^{97}$

U.S. naval relationships with Canada were also increased in other dimensions with Canada's eventual entry into the Korean War with the deployment of Canadian naval vessels highlighted by the Canadian command of a task element with Australian, Canadian, and U.S. vessels. In addition, it was further increased through the Naval Tripartite Standardization Program in 1950, a series of defense production sharing agreements that required the increasing standardization of military and naval equipment between the two countries, the establishment of the bilateral North American Air Defence Agreement (NORAD) in 1957, and from 1968 participation alongside the United States and other NATO naval vessels in the Standing Naval Force, Atlantic. ${ }^{68}$

While the United States gave priority to retaining and expanding upon its World War II naval relationship with Canada on the grounds of North American defense, the creation of NATO gave it added emphasis and focus. However, the renewals of American naval relations with Australia and New Zealand were not long delayed. This came in 1950 just as the first major Cold War crisis occurred in the Pacific region.

In October 1950, the U.S. Joint Chiefs of Staff and the U.K. Chiefs of Staff agreed that it would be mutually beneficial for both Britain and the United States to establish working relationships with the navies of Australia and New Zealand on operational matters in the event they found themselves operating against a common enemy. In this regard, they agreed that planning should proceed toward the establishment of a boundary line for the allocation of responsibilities between the U.S. and Australia and New Zealand for matters of convoy routing, reconnaissance, local defense and antisubmarine warfare as well as search and rescue. This became known as the ANZAM (Australia, New Zealand, Malaya) Region. The talks to implement this took place at Pearl Harbor, attended by Admiral Arthur W. Radford for the United States, Vice-Admiral Sir John Collins, Chief of Naval Staff, Australia, and Commodore F.A. Balance, Chief of Naval Staff, New Zealand. ${ }^{69}$ The relationship established through this agreement has continued, and developed further in 1971 with the Royal Australian Navy joining Canada, Britain, and the U.S. in the naval standardization program that has facilitated the adaptation of appropriate NATO Standardization Agreements (STANAG) for use, along with communications, and technical cooperation programs. ${ }^{70}$

$66 \quad$ Ibid., 260.

67 Ibid.

68 John Heard Thompson and Stephen J. Randall, Canada and The United States: Ambivalent Allies $3^{\text {rd }}$ Edition (Athens, GA: University of Georgia Press, 2002), 194-196.

69 For a detailed study, see Thomas Durrell-Young, Australia, New Zealand, and United States Security Relations, 1951-1986 (Boulder, CO; Westview Press, 1986), and "ANZUS Naval Relations, 1951-85," in T.R. Frame, J.V.P. Goldrick, and P.D. Jones (eds.), Reflections on the Royal Australian Navy (Kenthurst, NSW: Kangaroo Press, 1991), 296-315.

70 Thomas Durrell-Young, Supporting Future U.S. Alliance Strategy: The Anglo-Saxon or 
Captain Stephen Jurika, USN, who was U.S. naval attaché in Australia in 195051 at the time of the Radford-Collins talks, helping to implement them, described the Australian navy as he remembered it at that time:

The navy has been assured that its needs will be met, regardless of costs. This is an indication to me that the Australian government recognizes that there is nothing like the Australian Navy in the defense of Australia. The Royal Australian Navy is a young and vigorous service, and its officer personnel do not have the stultified, parochial outlook on the world that so characterizes the average Australian. Cooperation with the U.S. and the Royal navies will keep the RAN abreast of developments both in weapons, equipment, and planning. ${ }^{71}$

For seventy of the past hundred years, Commonwealth navies have worked increasingly closely with the United States Navy and made major contributions to mutual national and alliance goals beginning with World War II and continuing to operations in progress today. ${ }^{72}$ Relatively few American naval officers over this past century have had the opportunity to see Commonwealth navies in a close-up perspective and even fewer have spent much time thinking about those navies, but the cooperation has been overwhelmingly successful despite some rough edges. Those Americans that have had the opportunity for developing close relationships with the officers of these navies have uniformly praised their professionalism and high morale.

The longest and closest relationship that the United States Navy has had among the Commonwealth navies has been quite naturally with the U.S.'s neighbor to the north, and also with the Royal Australian Navy. As the U.S. naval attaché in Canada has summarized it, the roots of this good relationship lie "in the day-to-day maritime operations in NATO, where we have a history of sailing together side by side for over 60 years with the NATO Standing Maritime Forces - interoperability between our navies is not a new idea. This has evolved into a relationship where Canadian warships regularly operating as an equal partner in a USN Battle Group - a compliment and honor we afford no other nation (not even the UK).,"73

One former U.S. naval attaché explained that one of the rough edges is "simple arrogance since we're the guys with the aircraft carriers and big nuclear subs." " Another underscored the same problem by relating the story of the Supreme Allied Commander, Atlantic, who arrived in Ottawa in 1995 to tell senior Canadian defense and naval leaders, to the embarrassment of the U.S. embassy staff and the U.S. naval attaché, "I own $80 \%$ of the

“ABCA” Clue (Carlisle Barracks, PA: Strategic Studies Institute U.S. Army War College, 1 June 1990), 14-18.

71 Stephen Jurika, Jr., The Reminiscences of Captain Stephen Jurika, Jr., U.S. Navy (retired) (Annapolis: Naval Institute Oral History, 1979), Vol. II, 755-757.

72 See Commander Barry L. Coombs, USN, United States Naval Cooperation with Canada, Strategic Research Department Research Report 2-95 (Newport, RI: U.S. Naval War College, 1995).

73 Captain Stephen W. Jordan, USN, Naval Attaché, USDAO, Ottawa, e-mail to Hattendorf, 18 December 2009.

74 Captain David G. Clark, USN (ret), former U.S. naval attaché in Ottawa, e-mail to Hattendorf, 16 December 2009. 
world's power" and gave the impression that he perceived Canada's forces as being insignificant. $^{75}$

Those American naval officers who have worked closely on a daily basis with the Commonwealth navies have a much different story to tell. These officers explain, "They treasure the special relationship with the U.S. and work very hard to maintain it." 76 They point out the close working relationships they developed and openness with which they were able to communicate and discuss issues with officials.

Of course, there are points of policy differences and matters of political tension as there are also basic characteristics in the relationship that may be best described in the old lines, attributed to a Canadian admiral, that: "some nations have too much history; Canada has too much geography" and "being next to the USA is like sleeping with a fat lady; if she rolls over too fast, you are smothered."

While looking at Canada, several officers pointed out the lack of funding for the Canadian naval service, attributing this to political leaders who seemed to believe during the Cold War that Canada's geographic position between the U.S. and the Soviet Union would force the U.S. to provide for Canada's defense, while Canadian politicians could garner their votes by diverting defense dollars to social programs. ${ }^{78}$ Over several decades, American observers have often concluded that the Canadian navy received only minimal funding for its needs and that it required many years for it to obtain approval for the procurement of new equipment. Also, they believed that Canadian flexibility in ship procurement had been further limited by the restriction to national shipyard production.

To close by paying a special tribute on this occasion to the 'birthday navy' on this auspicious anniversary - and hopefully not to slight the Royal Navy and the other Commonwealth navies whose representatives are also present at this conference - American naval officers point out with continuing appreciation the Canadian navy's effective initiative in preparing the ready alert naval squadron for deployment as a response to the $9 / 11$ attack in 2001, and its skilful development of specialized operational procedures for boarding vessels in opposed and hostile situations during the Persian Gulf wars.

American officers have admired without qualification the professionalism of the officers and men of Commonwealth navies and their ability to maximize the use of their force structures, taking their training very seriously while at the same time making it an effective improvement in the fleet. The tradition of naval cooperation that was begun during World War II, in both the Atlantic and the Pacific, has continued with both Canada and Australia in Korea, with Australia in Vietnam, and with recent Canadian, Australian and New Zealand naval participation in the Persian Gulf conflicts.

75 Captain James "Randy" Stapleford, USN (ret.), U.S. naval attaché in Ottawa 1995, telephone conversation with Hattendorf, March 2010.

76 Captain Duane J. Phillips, USN (ret.), U.S. naval attaché in Ottawa, June 2000-May 2003, email to Hattendorf, 26 February 2010.

77 Captain David G. Clark, USN (ret.) e-mail to Hattendorf, 15 December 2009.

78 Clark, e-mail, 16 December 2009; Phillips e-mail 26 February 2010; Captain John G. Colgan, USN (ret.) U.S. naval attaché in Ottawa, August 1981-August 1985, telephone conversation with Hattendorf, February 2010. 